\title{
RISIKO KONTAMINASI BAKTERIOLOGIS PADA SARANA AIR BERSIH DI DESA BARUH TABING KECAMATAN BANJANG
}

\author{
Imam Santoso, Maharso, Darmiah \\ Poltekkes Kemenkes Banjarmasin Jurusan Kesehatan Lingkungan \\ Jl.H.M.Cokrokusumo No.1A Kota Banjarbaru \\ Email: imamsantoso165@gmail.com
}

\begin{abstract}
The bacteriological contamination risk of clean water facilities in Desa Baruh Tabing, Banjang Sub district. The Indonesian government as part of the population of the world is committed to achieving the Millennium Development Goals (MDG), particularly in the field of Water Supply and Sanitation (WSS) which lowers the number of people who do not have access to drinking water and basic sanitation by $50 \%$ in 2015 . However, drinking water coverage in 2010 amounted to $48.8 \%$ for the physical. This study aims to determined differences in the bacteriological quality of water is based on the type of water supply system in the Desa Baruh Tabing at Banjang's Puskesmas working area. Using a cross sectional study design. A sample of 9 pieces of SAB with the sampling method performed Saturation Sampling. The sampling period was done three (3) times in one month on each of clean water facilities to be checked, so the total number of water samples of 27 samples. Analysis used ANOVA test. The results showed no significant difference between the numbers of clean water facilities with $\mathrm{p}=$ 0.010 at $\alpha=0.05$; bacteriological quality (number of coliform) the highest number is 1,898 , while the lowest is zero. For the average value of the highest coliform number 1,898 on Dug wells. While the risk of coliform contamination in water supply facilities in the high category as much as $44.4 \%$ and $11.1 \%$ very high category. To keep the risk of coliform contamination of the water supply facilities, monitoring is done periodically by the authorities.
\end{abstract}

Keywords: the risk of contamination; bacteriological; clean water facilities

Abstrak: Perbedaan risiko kontaminasi bakteriologis pada sarana air bersih (sab) di Desa Baruh Tabing Kecamatan Banjang. Pemerintah Indonesia sebagai bagian dari penduduk dunia berkomitmen untuk mencapai target Millenium Development Goals (MDG) khususnya di bidang Water Supply and Sanitation (WSS) yaitu menurunkan jumlah penduduk yang tidak memiliki akses terhadap layanan air minum dan sanitasi dasar sebesar $50 \%$ pada tahun 2015 . Namun cakupan air minum pada tahun 2010 sebesar 48,8\% untuk fisik. Penelitian ini bertujuan mengetahui perbedaan kualitas bakteriologis air berdasarkan jenis sarana air bersih di Desa Baruh Tabing Wilayah kerja Puskesmas Banjang. Desain penelitian menggunakan Cross Sectional. Sampel sebanyak 9 buah SAB dengan metode pengambilan sampel dilakukan secara Saturation Sampling. Periode pengambilan sampel dilakukan 3 (tiga) kali dalam satu bulan pada masing-masing SAB yang akan diperiksa, sehingga jumlah seluruh sampel air sebanyak 27 buah sampel. Analisis menggunakan uji Anova. Hasil penelitian menunjukkan ada perbedaan signifikan antara sarana air bersih terhadap angka coliform di Desa Baruh Tabing dengan nilai $p$ $=0,010$ pada $\alpha=0,05$; kualitas bakteriologis (angka Coliform) yang tertinggi mencapai 1.898, sedangkan terendah nol. Untuk nilai rata-rata angka Coliform tertinggi 1.898 pada Sumur Gali. Sedangkan risiko kontaminasi coliform pada sarana air bersih pada kategori tinggi sebanyak $44,4 \%$ dan sangat tinggi $11,1 \%$. Untuk menjaga adanya risiko kontaminasi coliform terhadap sarana air bersih, dilakukan pengawasan secara berkala oleh pihak yang berwenang.

Kata kunci : risiko kontaminasi, baktriologis, sarana air bersih. 


\section{PENDAHULUAN}

Masalah penyediaan air bersih ini menjadi salah satu prioritas dalam perbaikan derajat kesehatan masyarakat. Mengingat keberadaan air sangat vital dibutuhkan oleh makhluk hidup. Kehidupan di muka bumi ini hanya dapat berlangsung dengan keberadaan air. Seiring meningkatnya kepadatan penduduk dan pesatnya pembangunan, maka kebutuhan air pun semakin meningkat. Sehingga dituntut tersedianya air yang sehat yang meliputi pengawasan dan penetapan kualitas air untuk berbagai kebutuhan dan kehidupan manusia yang bertujuan untuk menjamin tercapainya air minum maupun air bersih yang memenuhi syarat kesehatan bagi seluruh lapisan masyarakat.

Air yang digunakan harus memenuhi syarat dari segi kualitas maupun kuantitasnya. Secara kualitas, air harus tersedia pada kondisi yang memenuhi syarat kesehatan. Kualitas air dapat ditinjau dari segi fisika, kimia dan biologi. Air yang dapat digunakan untuk keperluan sehari hari harus memenuhi standar baku untuk air rumah tangga. Kualitas air yang baik ini tidak selamanya tersedia di alam. Adanya perkembangan industri dan pemukiman dapat mengancam kelestarian air bersih.

Permasalahan kesehatan masyarakat di Indonesia masih ditandai dengan tingginya angka kesakitan dan kematian penyakit yang berbasis lingkungan, seperti tifoid, polio, cacingan dan diare. Data yang ditunjukkan bahwa 2 dari 4 penyakit penyebab kematian balita adalah Diare dan Typus akibat sanitasi buruk(1).

Berbagai upaya telah dilakukan untuk mengatasi permasalahan tersebut diatas, satu diantaranya adalah intervensi lingkungan melalui peningkatan penyediaan air minum dan sanitasi, namun demikian berdasarkan laporan WHO - Unicef Joint Monitoring Pragramme tahun 2004 kinerja sektor air minum dan sanitasi di Indonesia dinilai masih rendah jika dibandingkan dengan Negara Asia Tengara lainnya( ${ }^{(1)}$.

Pemerintah Indonesia sebagai bagian dari penduduk dunia berkomitmen untuk mencapai target Millenium Development Goals (MDG) khususnya di bidang Water Supply and Sanitation (WSS) yaitu menurunkan jumlah penduduk yang tidak memiliki akses terhadap layanan air minum dan sanitasi dasar sebesar $50 \%$ pada tahun 2015(2).

Cakupan air bersih di Kabupaten Hulu Sungai Utara Pada tahun 2010 sebesar $57,6 \%$, sedangkan cakupan air minum pada tahun 2010 sebesar 48,8\% untuk fisik. Cakupan kualitas air bersih terjadi peningkatan dibandingkan dengan tahun 2009 yaitu 30,5\% (Profil Dinkes Kab.HSU, 2010). Menurut data yang diperoleh dari Dinas Kesehatan Kabupaten Hulu Sungai Utara, tahun 2010, bahwa jumlah sarana air bersih yang ada di Kabupaten Hulu Sungai Utara sebanyak 7.606 buah, sedangkan untuk Kecamatan Banjang jumlah sarana air bersih sebanyak 570 buah(3).

Berdasarkan hasil data Program yang berkaitan dengan Sanitasi dan air bersih (PAMSIMAS) dan data dari hasil Inspeksi sanitasi Puskesmas Banjang menunjukan bahwa dari 1204 buah sarana air bersih yang digunakan sebagai sumber air minum ditinjau kualitas fisik memenuhi syarat 481 buah $(39,95 \%)^{(4)}$. Keberadaan Sarana Air Bersih (SAB) baik dari Bakteriologis dan segi konstruksinya maupun jarak peletakan terhadap sumber pencemaran masih sangat memprihatinkan disebabkan karena adanya konstruksi SAB yang tidak memenuhi syarat kesehatan dan letaknya kurang diperhatikan, sehingga mempunyai resiko tinggi terjadinya pencemaran kualitas air baik yang berasal dari jamban, sampah dan dari air buangan lainnya(3).

\section{BAHAN DAN CARA PENELITIAN}

Desain penelitian yang digunakan berdasarkan tujuan, mengguankan penelitian Analitik dengan pendekatan Cross Sectional(5).

Populasi dalam penelitian adalah sarana air bersih (SAB) yang digunakan untuk air minum dan minimal 1 tahun digunakan oleh penduduk Desa Baruh Tabing Kecamatan Banjang wilayah Kerja Puskesmas Banjang sebanyak 9 buah, terdiri dari 3 buah sumur gali (SGL), 2 buah Sumur Pompa Tangan (SPT), dan 4 buah sumur bor (BOR). Sampel dalam penelitian adalah seluruh sarana air bersih (SAB) di Desa Baruh Tabing sebanyak 9 buah SAB dengan metode pengambilan sampel dilakukan secara Saturation Sampling. Periode 
pengambilan sampel dilakukan 3 (tiga) kali dalam satu bulan pada masing - masing sarana air bersih yang akan diperiksa, sehingga jumlah seluruh sampel air sebanyak 27 buah sampel.

Sampel air diukur dan pemeriksaan oleh Laboratorium Dinas Kesehatan Kabupaten Banjar, sedangkan inspeksi sanitasi sarana air bersih dilakukan oleh Petugas Sanitarian Puskesmas Banjang. Instrumen observasi menggunakan Peraturan Kemenkes RI No.736/MENKES/PER/VI/2010 tentang Tata laksana pengawasan kualitas air minum.

Data yang diperoleh diolah dengan menggunakan bantuan komputer program Statistik. Penyajian data dilakukan dalam bentuk tabel distribusi frekuensi, grafik, dan tabel silang antara variabel bebas dengan variabel terikat.

Setelah diketahui karakteristik masing-masing variabel dapat diteruskan analisis lebih lanjut, tujuannya untuk diagnosis data dan melakukan uji hipotesis dua variabel. Analisis dalam penelitian ini menggunakan statistik Uji Anova.

\section{HASIL PENELITIAN DAN PEMBAHASAN Hasil Penelitian}

1. Kualitas bakteriologis (angka coliform)

Data jenis SAB dalam penelitian ini antara lain : 2 Sumur pompa tangan (SPT), 3 sumur gali (SGL), dan 4 Sumur Bor (BOR). Secara rinci kualitas bakteriologis (angka coliform) Sarana Air Bersih ditampilkan pada tabel berikut ini.

Tabel 1. Jenis Sarana Air Bersih (SAB) dan Rata-rata Kualitas Bakteriologis (Angka Coliform) di Desa Baruh Tabing Kecamatan Banjang

\begin{tabular}{llrrrr}
\hline \multirow{2}{*}{ No. } & \multirow{2}{*}{ Jenis SAB } & \multicolumn{3}{c}{ Angka Coliform } & \multirow{2}{*}{ Rata-rata } \\
\cline { 2 - 4 } & Ulangan_1 & Ulangan_2 & Ulangan_3 & 78 \\
\hline 1. & SPT_1 & 233 & 0 & 0 & 633 \\
2. & SPT_2 & 1.898 & 0 & 0 & 1.898 \\
3. & SGL-1 & 1.898 & 1.898 & 1.898 & 1.280 \\
4. & SGL_2 & 45 & 1.898 & 1.898 & 1.266 \\
5. & SGL_3 & 2 & 1.898 & 1.898 & 0 \\
6. & BOR_1 & 0 & 0 & 0 & 3 \\
7. & BOR_2 & 0 & 0 & 8 & 0 \\
8. & BOR_3 & 0 & 0 & 0 & 731 \\
\hline 9 & BOR_4 & 294 & 1.898 & 2 & \\
\hline
\end{tabular}

Pada tabel.1 dapat diketahui bahwa angka coliform yang tertinggi mencapai 1.898, sedangkan terendah nol. Untuk nilai rata-rata angka Coliform 1.898 pada Sumur Gali (SGL_1) dan angka coliform nol pada sumur Bor (BOR_1 dan BOR_3). b. Kategori Risiko Kontaminasi

Setelah dilakukan pengamatan dan penilaian terhadap SAB, maka diperoleh nilai kategori risiko kontaminasi oleh coliform yang ditampilkan pada tabel berikut ini.

Tabel 2. Distribusi frekuensi kategori risiko kontaminasi Coliform pada SAB di Desa Baruh Tabing Kecamatan Banjang Kab. HSU

\begin{tabular}{|c|c|c|c|}
\hline No & Kategori Risiko & Frekuensi & Persentase (\%) \\
\hline 1 & Rendah & 3 & 11.1 \\
\hline 2 & Sedang & 9 & 33,3 \\
\hline 3 & Tinggi & 12 & 44,4 \\
\hline 4 & Sangat tinggi & 3 & 11,1 \\
\hline & Jumlah & 27 & 100 \\
\hline
\end{tabular}


Berdasarkan tabel.2 terlihat risiko kontaminasi coliform pada SAB masuk dalam kategori Tinggi sebanyak 44,4\% dan Amat Tinggi $11,1 \%$. Untuk melihat angka Coliform pada masing-masing Kategori risiko kontaminasi dpat diketahui pada tabel berikut.

Tabel 3. Rata-rata (Mean) Angka Coliform menurut kategori risiko kontaminasi pada SAB

\begin{tabular}{clr}
\hline No. & Risiko Kontaminasi & \multicolumn{1}{c}{ Mean } \\
\hline 1. & Rendah & .00 \\
2. & Sedang & 211.78 \\
3. & Tinggi & 838.83 \\
4. & Sangat tinggi & 1898.00 \\
\hline c. & \multicolumn{2}{c}{ Analisis data menggunakan Uji }
\end{tabular}
Anova diperoleh nilai $\mathrm{p}=0,010$ yang artinya terdapat perbedaan yang bermakna risiko kontaminasi sarana air bersih dengan kualitas bakteriologis air. Untuk melihat kelompok sarana air bersih mana yang terdapat perbedaan, dapat dilihat pada analisis Post Hoc, diperoleh hasil: kategori risiko kontaminasi rendah dengan amat tinggi, nilai $\mathrm{p}=0,005$; kategori risiko kontaminasi sedang dengan sangat tinggi, nilai $\mathrm{p}=0,003$; kategori risiko kontaminasi tinggi dengan sangat tinggi, nilai $\mathrm{p}=0,039$. Dengan demikian, perbedaan kualitas bakteriologis air berbeda secara bermakna pada semua kategori risiko kontaminasi sarana air bersih. Adapun kurva perbedaan Kategori Risiko Kontaminasi dengan ratarata angka coliform dan kurva perbedaan sarana air bersig dengan rata-rata angka coliform dapat dilihat pada gambar dibawah ini.

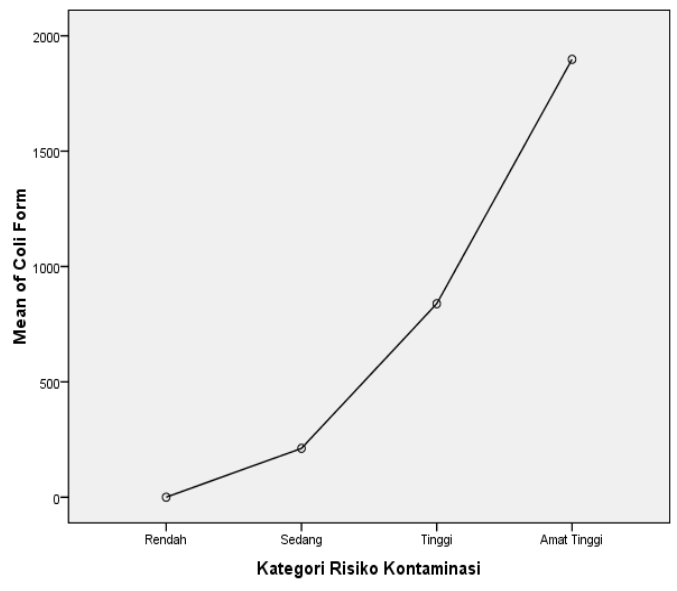

Gambar 1. Kurva Kategori Risiko Kontaminasi dengan Mean Coliform

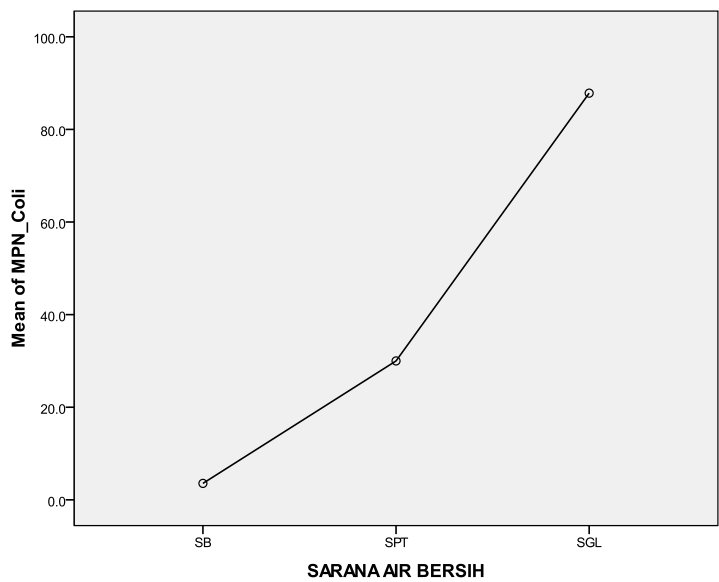

Gambar 2. Kurva Sarana Air Bersih dengan Mean Coliform 


\section{PEMBAHASAN}

\section{Kualitas Coliform) \\ Bakteriologis \\ (Angka}

Berdasarkan Peraturan Menteri

Kesehatan RI No. 416 Tahun 1990 tentang persyaratan air minum(6), maka air tersebut harus bebas dari coliform tinja, dimana untuk air bersih jumlah total coliform adalah 10 per $100 \mathrm{ml}$ (air perpipaan), 50 pen $100 \mathrm{ml}$ untuk air bukan perpipaan, dan air tersebut harus bebas dari bakteri Echerisia coli. Pada tabel 1 menunjukkan bahwa sumur bor (BOR_1 dan BOR_3) telah memenuhi persyaratan Kesehatan, namun sarana air bersih lainnya tidak memenuhi persyaratan kesehatan yang ditetapkan oleh Kementerian Kesehatan RI(7). Dapat dikatakan bahwa hanya 2 sarana air bersih $(22,2 \%)$ di Desa Baruh Tabing yang menjadi sampel telah memenuhi persyaratan kualitas air minum, selebihnya 7 sarana air bersih $(77,8 \%)$ tidak memenuhi persyaratan kesehatan. Fenomena ini dapat diartikan bahwa masyarakat Desa Baruh Tabung mempunyai potensi untuk terkena penyakit (water borne diseases) yang ditimbulkan oleh mengkonsumsi air yang tidak memenuhi persyaratan kesehatan, misalnya: diare, gastroentritis.

\section{Kategori Risiko Kontaminasi}

Hasil pengamatan langsung yang dilakukan oleh Petugas Sanitarian Puskesmas Banjang menunjukkan bahwa ada 44,4\% sarana air bersih yang digunakan oleh masyarakat Desa Baruh Tabing mempunyai kategori risiko kontaminasi oleh coliform tergolong "tinggi", ditambah $11,1 \%$ kategori "sangat tinggi". Sedangkan sisanya masuk kategori "rendah" sebanyak $11,1 \%$ dan "sedang" sebanyak 33,3\%. Fenomena ini memperlihatkan bahwa risiko kontaminasi sarana air bersih terhadap kontaminasi coliform (yang menjadi persyaratan air minum) masih besar dan perlu mendapatkan tindak lanjut dalam pengendalian risiko kontaminasi. Menurut daftar isian observasi sarana air bersih menunjukkan bahwa penilaian risiko yang muncul berkenaan dengan adanya sumber pencemar lainnya (misal: kotoran hewan, sampah); tidak ada sistem pembuangan air limbah; tidak ada lantai di sekeliling sumur sehingga air mudah mencemari; sumur tidak tertutup rapat sehingga mempunyai risiko terkontaminasi.

\section{Analisis statistik}

Analisis statistik bertujuan untuk mengetahui perbedaan antara sarana air bersih terhadap angka coliform yang terdapat pada masing-masing sarana air bersih di Desa Baruh Tabing dengan menggunakan statisti Uji Anova. Hasil analisis menunjukkan bahwa nilai probalitas sebesar 0,010 pada alpha sebesar 0,05 . Karena nilai $\mathrm{p}<\alpha$ maka dapat diartikan bahwa hipotesis nol ditolak, dengan interpretasi ada perbedaan antara sarana air bersih terhadap angka coliform. Pada gambar 1 memperlihatkan bahwa garis trend/kecenderungan angka coliform meningkat pada sarana air bersih yang mempunyai kategori risiko kontaminasi "sangat tinggi". Berdasarkan kurva tersebut dapat diprediksikan bahwa sarana air bersih di Desa Baruh Tabing jelas mempunyai risiko tinggi dan sangat tinggi terkontaminasi oleh coliform dari kotoran manusia. Fenomena tersebut didukung oleh kondisi lingkungan sarana air bersih yang buruk, dimana adanya sumber pencemar lainnya yang mengkontaminasi sarana air bersih, sistem pembuangan air limbah, dan sarana air bersih tanpa tutup yang memudahkan terkontaminasi oleh coliform.

\section{KESIMPULAN DAN SARAN}

Sarana air bersih mempunyai kategori risiko kontaminasi terhadap coliform termasuk tinggi $44,4 \%$ dan amat tinggi $11,1 \%$. Sedangkan sarana air bersih jenis bor (hanya BOR_1 dan BOR_3) mempunyai angka coliform yang memenuhi persyaratan kesehatan. Secara keseluruhan terbukti secara statistik ada perbedaan signifikan risiko kontaminasi sarana air bersih dengan kualitas bakteriologis air di Desa Baruh Tabing. Untuk menjaga adanya risiko kontaminasi coliform terhadap sarana air bersih, dilakukan pengawasan secara berkala oleh pihak yang berwenang, terutama petugas Sanitasi Puskesmas Banjang. 


\section{KEPUSTAKAAN}

1. Direktorat Penyehatan Lingkungan. Panduan Sistem Surveilans Air Minum dan Sanitasi. Dirjen PP-PL Jakarta, 2011

2. Departemen Pekerjaan Umum. Program Penyediaan Air Minum dan Sanitasi Berbasis Masyarakat (PAMSIMAS) Air Untuk Kehidupan. Dirjen Cipta Karya,. Jakarta, 2009

3. Pusat Kesehatan Masyarakat Kecamatan Banjang, Profil Kesehatan Puskesmas Banjang Tahun 2010, Banjang 2010

4. Dinas Kesehatan Kabupaten Hulu Sungai Utara. Profil Kesehatan Tahun 2009. Amuntai, 2009

5. Santoso Imam, Manajemen Data Untuk Analisis Data Penelitian Kesehatan. Gosyen Publishing, Yogjakarta, 2013

6. Depkes RI. Prosedur Tetap Pengawasan dan Perbaikan Kualitas Air Bersih dan Sanitasi Pada Kejadian Bencana dan Pengungsian, Direktorat Penyahatan Lingkungan, Dirjen PP - PL. Jakarta, 2006

7. Departemen Kesehatan. Pedoman Umum Penyediaan Sarana Air Minum dan Sanitasi Berbasis Masyarakat (PAMSIMAS KOMPONEN - B), Direktorat Penyehatan Lingkungan, Dirjen PP - PL Jakarta, 2009. 